\title{
ARTIGOS
}

\section{A LIÇÃO DE UMA CANÇÃO DE GESTA: OS NARBONESES (1)}

Neste estudo só se considerará uma parte do poema (2), que data dos primeiros anos do século XIII, e cujo teor pode resumirse do seguinte modo:

O conde Aymeri de Narbonne declara a seus sete filhos, que alcançaram a idade de se tornarem cavaleiros, que chegou o momento de irem tentar fortuna fora do feudo paterno. Sòmente o mais jovem ficará en Narbonne, a fim de, um dia herdar o condado. Dos outros seis, dois, chamados Guerino e Buève, têm diante de si uma carreira que se apresenta bastante fácil: Guerino irá à côrte de seu tio, o rei Bonifácio da Lombardia, que não tem filhos e lhe legará o seu reino. Buève tem probabilidades de casar-se com a filha única do rei Yon da Gasconha, e, se o casamento se realizar, obterá, na sucessão de seu sogro, a corôa da Gasconha.

Dêsse modo, Gucrino e Buève parecendo estarem destinados a conseguir heranças reais, restam ainda quatro filhos: Bernardo, Guilherme, Arnaldo e Aümer, que, para atingir posição digna de seu nascimento, devem, por leais serviços grangear. a proteção do rei da França. A lendária bravura de seu pai, aliás, fará com que o soberano lhes dedique especial atenção.

(Êsse soberano chama-se Carlos ou Carlos Magno. Do mesmo modo, porém, que o capetíngio.que reinava na França quando da composição do poema, reside habitualmente em París).

Aymeri de Narbome envia, pois, a París quatro de seus filhos, a fim de se apresentarem a Carlos Magno e lhe dizerem que seu pai solicita para o mais velho, Bernardo, a dignidade de par e um cargo de conselheiro, para Guilherme, o cargo de conduzir o estandarte em batalha, isto é, a dignidade de porta-estandarte, e para Arnaldo o cargo de senescal. Pois são êsses, na França, os trềs cargos de mais elevada categoria da côrte, diz o velho conde Aymeri. Quanto a Aïmer, o único favor que pedirá será o de ir combater os sarracenos da Espanha, para constituir para si um reino à custa dêles.

A condessa Hermengarda, esposa de Aymeri, bem quis $\in$ ra conservar junto de si seus filhos. Suas lágrimas, porém, não conseguiram mudar a resolução de seu marido. Ô vello conde também ficou insen-

(1). - Texto francês traduzido pelo licenciado Moisés Rovner.

(2). - A edição utilizada foi a de $H$. Suchier (Société des Anciens Textes Français), em dois volumes, 1898. 
sivel às súplicas dos habitantes de Narbonne, no ssntido de não deixar que seus filhos partissem.

Chega o dia em que os jovens se põem a caminho, acompanhados. de cêrca de trinta jovens nobres ou filhos de ricos burgueses que quiseram tentar fortuna junto dêles. A condessa, receando que seus filhos não estejam suficientemente providos para aparecerem dignamente à côrte de Carlos, faz com que os sigam, conduzidos por seus camareiros, quatro mulos carregados de ouro e objetos preciosos. Seus. filhos, ao s.rem alcançados por êsse séquito, mandam-no embora, com bastante rudeza, dizendo que não precisam dêle, e é com grande desencanto que a condessa vê regress:ur, lastimosamente, a Narbơnne, os. seus camareiros e os mulos.

Em caminho, os jovens narboneses encontram um bispo, accmpanhado de trinta cônegos, que lhes declara estar, também, a caminho de Farís. "Carlos reune sua côrte", diz-lhes êle, "e vou para lá, ccmo êsses cônegos... Vou dirctamente a Auvergne, dspois a Berry, e de lá irei para a França, até onde estiver o rei" (v. 1685-1690). (Com efeito, no poema, Carlos Magno é qualificado ora de imperador, ora de rei).

Arnaldo, um dos filhos de Aymeri de Narbonne, responde-lhe: "Somos vinte ousados bacheliers e também queremos ir à côrte" (sabe-se que a palavra bacheliers, na língua dêsse tempo, significa "jovem nobre") "mas receamos perdsr-nos em caminho, pois jamais viemos até aqui". O bispo concorda com que viajem com êle, e sua boa vontade é ainda maior porque êle é primo da condessa Hermengarda, a mãe dêles (v. 1732). Assim, todos juntos (v. 1750),

De Ricordene pasent les grans destrois (3)

Passam os grandes desfiladeiros de Ricordene.

Após haverem ultrapassado Clermont-Ferrand, encontram os viajantes um temível salteador, que os jovens narboneses conseguem aprisionar. Antes de enforcá-lo, fazem-no falar. O salteador confessa-lhes que, ainda na véspera, atacara e roubara a bagagem ao rico séquito. de alto prelado que se dirigia

Al parlement à Paris la cité (v, 1822). (Vide nota 4)

Ao Parlamento (Côrte de Justiça) na ilha de París.

Prosseguindo o seu caminho, os narboneses aproximam-se de París, transpõem o Loire, pela ponte de Orleans, e entram na França (v. 1857).

Parmi la Biause se sont acheminé.

Jusq'a Estanpes ne se sont aresté.

llecques sont une nuit cstelé,

Et puis en sont al matinet torné.

Par Estrichi sont li baron pasé;

Ce jor ont tant chevalchié et crré

Que Paris voient, la mirable cité,

Et mainte iglisse et maint clochier levé,

Les abaïes de grant nobilité,

(3). - Ricordene ou Regordane é o nome popular que, na Idade Média, tinha a via que ligava o Auvergne a Languedoc pela passagem que a estrada de ferro de Clermont a Nimes atravessa, atualmente, em La Bastide, ao sul de Langogne. Essa via foi, antes da conquista romana, o eixo de um império arverne que Estrabão (IV, 2, 3) diz que se estendeu até Narbonne. 
Et voient Saine, dont parfont sont li gué,

Et les molins, dom il ot planté,

Voient les nes qui amcinent le blé,

Le vin, le sel et la grant richeté. (v. 1865-1877).

(Avançaram pela Beauce e não pararam senão $\mathrm{\epsilon m}$ Étampes, onde pernoitaram. Ao amanhecer, continuaram os nobres a viagem, passando por Estrichi; tanto cavalgaram e vaguearam, nesse dia, que viram $\mathrm{Pa}$ ris, a admirável cidade, muitas igrejas c muitas tôrres altas; as abadias de grand z nobreza, o. Sena, cujo leito é profundo, e os moinhos que nêle há. Vêem os barcos que trazem o trigo, o vinho, o sal e a grande riqueza).

No momento em que vão entrar em París, encontram o cortejo do abade de Cluny, que sai da cidade acompanhado de quinz: monges (v. 1895-1897). Arnaldo, aquêle dentre os jovens narboneses a quen o pai gostaria de ver investido do cargo de senescal de Carlos Magno, interpsla o grupo de cclesiásticos: "Dizei-me, senhores monges, ondè é que parastes? Que encontrastes em Faris? Vistes Carlos, o poderoso rei coroado?" - "Amigos, diz o abade, na verdade, o rei reune sua côrte com grande e rica afluência de nobres. Seu número é tão grạımde que eu não poderia sequer contar a inctade. Em París, na cité (4), não existe salão, palácio, casa, adega, nem celeiro que não es't ja repleto de duques, condes, príncipes, arcebispos, bispos, abades, padres e clérigos. E por isso que estou voltando, pois não $\in$ encontro hospedagem en lugar algum. Pernoitarei em alguma cela de mosteiro, de onde voltarei, amanhã, a París, a fim de dar meus conselhos nas câmaras de Carlos, do que tenho a incumbência" (v. 1900-1922).

O jovem Arnaldo, porém, irrita-se por ver que o abade logo desanima. "Sou senescal de todo êste reino", diz (dando-se audaciosamente, o título que seu pai desejava que obtivisse), "e não terei dificuldade em pôr à vossa disposição tantos hotéis quantos quiserdes". O abade acha graça na segurança com que fala o jovem. Tenta suavemente fazer com que compreenda que se está iluclindo, repete-lhe que tôda a París está replcta, que reis, arcebispos, bispos, duques, cavaleiros, príncipes e marqueses tomaram todos os lugares. "Ocuparam até os alpendres das casas, e mais de quinlentas pessoas deitam-se nas vias. Julgo preferivel que volteis conosco. Há, a sete léguas daqui, um bom castelo, bem provido de pão, vinho e carne: é Montléry. Aí nos aloja-

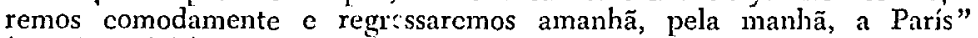
(v. 1943-1951).

Arnaldo nada quer ouvir. Chama os monges de covardes, proclama novamente o seu título de senescal e mostra-se ameaçador. Termina por impor-se ao abads, que, voluntàriamente ou não, volta a París com seus monges, atrás dos narboneses. Ei-los "em a grã rua" ( $v$. 1987). Assim se denomina, no século XIII, a via pela qual se entra em París quando se vem de Orléans. Seu nome, no século XIV, será rua Saint-Jacques, nome que ainda hoje conserva (5). Arnaldo avista, nessa rua, uma imponente vivenda, com contrafortes e ameias. Sem apear, entra no pátio, onde vê pessoas ocupadas en polir couraças, lustrar espadas, cuidar de cavalos e levar víveres à cozinha. Cêrca de quarenta jovens nobres - êsse número considerável mostra que se tra-

(4). - Cité:ilha do rio Sena, que constitui a parte mais antiga e central de París. (Nota do Tradutor).

(5). - VIARD (J.): Documents parisiens sur le règne de Philippe VI de Valois, 1899 , t. II, p. 294 e 311 . 
ta do séquito de un senhor de alta classe - fizeram com que se estendesse no chão um tapête, no qual sentam e jogam xadrez.

"A quem é que fizeram morar aqui?" - pergunta altivamente Arnaldo. Respondem-lhe que é o duque de Borgonha, que foi chamado à côrte a fim de dar seus conselhos nas câmaras de Carlos Magno. "Eu sou senescal, replica Arnaldo, e estou encarregado da guarda de París. $O$ duque de Borgonha fêz muito mal em alojar-se aqui sem pedir permissão para isso. Saiam todos daqui e procurem pousada em outro lugar!" Começam a desafiar-se, depois lutam, e Arnaldo corre o risco de ser morto, quando lhe correm em socorro os seus irmãos, e, empregando tudo o que lhes cai às mãos como projétil, derrotam os homens do duque de Borgonha, que fogem. No lugar do duque, instala Arnaldo o abade de Cluny e seus monges, que, nessa grande casa, sentem-se muito à vontade para

Dire matines et lor vepres chanter (v. 2075).

(Dizer matinas e cantar suas vésperas).

Depois, os jovens narboneses põem-se à procura de outros alojamentos. Encontram logo o seu irmão, Guerino, em companhia de seu tio, o rei Bonifácio, que vem assistir à reunião da côrte de Carlos Magno, e que também está muito inquieto por não poder encontrar hospedagem. Arnaldo vai prestar-lhe o mesmo serviço que ao abade de Cluny: Nota, na Cité, próximo à Pequena Ponte, um magnífico palácio - o mais belo depois do de Carlos Magno - construído sôbre pilares, acima de um braço do Sena (v. 2110-2119). Aí habita um enviado do papa, com dois arcebispos. Arnaldo recomeça a sua manobra. Entra, a cavalo, no palácio e pergunta com altivez: "Quem sois? Quem teve a audácia de alojar-vos aqui, sem minha permissão?" - "Parece que bebestes um pouco demais, responde-lhe o arcebispo, e boa correção mereceríeis, pois é com ordem de Carlos Magno que ocupamos êste palácio. Ele -mesmo veio, em pessoa, aqui instalar-nos". Amaldo nấo tie deixa intimidar e, ajudado por seus irmãos, entra em luta com os soldados do legado pontifical, luta que não tarda $\mathrm{cm}$ ser vencida pelos narboneses. Os prelados abandonam o lugar e, aterrorizados, vão pernoitar debaixo da tenda, num prado, à beira do Sena, enquanto o rei Bonifácio e sua comitiva se instalam no palácio, elogiando entusiàsticamente a Arnaldo (v. 2128-2285).

Finalmente, os jovens narboneses, por sua vez, procuram pousada. No momento em que começam a procura, encontram o seu irmão Buève, igualmente atraído pela convocação da côrte, ao mesmo tempo que - o rei Yon da Gasconha, com cuja filha já se casara. Buève reune-łe a êles, assim como, aliás, Guerino, e ei-los que, todos os seis, saem da Cité, pela Grande Ponte, transpõem o Sena e percorrem as ruas da margem direita, chamando a atenção dos transeuntes por sua impressionante semelhança e boa presença (v, 2307-2320). Cai a tarde. Começam a ficar muito desanimados por não terem conseguido hospedagem (v. 2330-2331). Arnaldo tem uma idéia: põe-se à procura do hotel em que se hospedava o bravo Rolando, sobrinho de Carlos Magno. Um velho cônegó indica-lhe, com a ponta de sua luva, a direção: "Senhor cavaleiro, diz' a Amaldo, é mais longe, na encruzilhada, em casa do normando Anquetino. Era lá que, em vida, o conde costumava ir". (v. 2332-2339).

Esse hotel, porém, está cheio, como todos os outros. Aqui, os ocupantès são alemães, que tomam pensão há um mês. Estão à mesa quando os seis narboneses entram na sala. Arnaldo convida-os a pro- 
curarem outra moradia, logo que tenham terminado a sua refeição, porque, diz êle, "êste hotel é meu, possuo-o por feudo direto, pois pertenceu ao bom conde Rolando". Os alemães não entendem do mesmo modo, e trava-se uma luta em que são vencidos. Abandonam n lugar, com satisfação, aliás, do hoteleiro, a quem haviam irritado, por serem avarentos.

Acomodam-se os narboneses no hotel e, imediatamente, mandam trazer carnes, aves domésticas, caça, bons peixes de água doce e salgada, e ainda muitos outros víveres; e, por fim, instrumentos musicais:

Giguent et harpent, viëles font soner,

L'ostel en font bondir et retinter,

(Fazem saltar e retinir o hotel, ao som de bandolins, harpas e violas),

enquanto o hospedeiro abençoa os céus por the haverem enviado fregueses tão pródigos em seus gastos (v. 2349-2463).

Enquanto isso, as vítimas dos narboneses, pelo menos as que podem fazê-lo sem sofrer ridículo, foram queixar-se a Carlos Magno. "Senhor, diz o legado pontifical, vós nos mandastes vir à vossa cốrte, mas alguns furiosos bateram e feriram nossos soldados e expulsaramnos a nós mesmos do palácio em que estávamos". Carlos Magno sente ferver-lhe o sangue, jura por São Dionísio que a falta será duramente expiada, e ordena que se fechem as portas da cité, a fim de se facilitar a procura dos culpados (v. 2227-2257).

Depois, são os alemães que vêm mostrar-lhe as pancadas que receberam, e contar como foram violentamente expulsos do hotel $\mathrm{cm}$ que se encontravam, pelos seis jovens que nele se instalaram em seu lugar. . Pela narração dêsses alemães, Carlos Magno sabe onde se acham hospedadọs os culpados e tem os seus sinais. São, dizem-lhe, seis jovens nobres de andar altivo, que de tal modo se parecem uns com os outros, que, certamente, são irmãos.

A captura dos narboneses não poderia tardar, e o seu caso tornase tanto mais inquietador quanto o seu hospedeiro, vendo voltar diante de sua porta um dos seus hóspedes alemães, tem com êle uma altercação, matando-o. Desta vez, os narboneses cessam de rir, e um dêles exprime o receio de que o rei os acuse dêsse homicídio (v. 2562). Os; três barões a quem Carlos Magno incumbira de irem prender os narbonsses em sua hospedaria encontram, no caminho, justamente o caldáver dêsse alemão, e um dêles diz: "Isto vai de mal a pior". Atrás dêles cavalga o abade de Saint-Denis, a quem Carlos Magno encarregou de efetuar a prisão dos culpados, quando fôssem apanhados.

A cena da prisão, porém, tem un desfecho imprevisto: o abade de Saint-Denis reconhece, nos jovens culpados, os filhos da condessa Hermengarda, que é a sua prima-irmã. Abraça êsses moços, a quem estava incumbido de trazer prisioneiros (v. 2610-2613). O próprio Carlos Magno se acalma, ao saber que se trata dos filhos de Aymeri de Narbonne.

Os seis narboneses vão, então, a palácio, magnificamente trajados, graças às liberalidades do abade de Saint-Denis, e Carlos Magno, que nada quer recusar ao bravo Aymeri de Narbonne, confere-lhes justamente os cargos e as honrarias que seu pai desejava para êles.

Todos os seis ajoelham-se, então, aos pés de Carlos Magno, a quem agradecem (v. 2771-2867). 
A princípio, não estamos muito dispostos a atribuir qualquer valor documentário a essa burlesca e inverossímil fantasia, na qual as narrativas de pugilatos parecem constituir o principal atrativo. Um exame mais atento da obra, porém, mostra que o historiador

- nela encontra, na realidade; um conjunto de testemunhos que, pela precisão e interêsse, ultrapassam os de muitos documentos históricos da mesma época.

A intenção do poeta, na última parte da narrativa, é muito clara. Seu objetivo consiste em colocar os jovens narboneses, perante a justiça real, em posição tão incômoda quanto possível, sem, todavia, acusá-los de qualquer crime que possa fazer com que percam a estima ou a simpatia do auditório. $E^{\prime}$ preciso que se receie pelo seu destino, que sejam vistos em caso verdadeiramente passível de fôrca, e do qual não seria razoável esperar que pudessem livrar-se, isto para que a comoção seja mais feliz e mais viva no momento em que, contra tôda expectativa, o soberano manifestar sua clemência.

Ora, justamente, os narboneses - e é aqui que principia a aparecer o interêsse histórico da narrativa - fazem exatamente o que devia fazer-se, bem nos primeiros anos do século XIII, para levar ao auge o descontentamento de Carlos Magno, de um Carlos Magno em que os ouvintes não têm dificuldade em reconhecer o rei que, na época, reinava (6). Sabia-se, nesse tempo, por mais de um exemplo, o que podia ser a cólera de Filipe-Augusto. Sabia-se, também, pelo menos nos ambientes aristocráticos a que se dirige o poeta, do que era necessário abster-se para se evitar tal cólera.

Entre os senhores que gozam da estima do rei, e aos quais particularmente perigoso seria ofender, um dos melhores, na côrte, é, então, o duque de Borgonha, Eudes III, dócil executor.das vontades de Filipe-Augusto. Foi justamente a êsse grande favorito que os im-prudentes narboneses expulsaram do palácio em que se alojara.

$\mathrm{Na}$ côrte, o personagem que ocupa a posição mais elevada, que está à frente do Conselho Real, é o tio materno do rei, Guilherme de Champagne, legado pontifical e arcebispo de Reims. Filipe-Augusto foi sagrado por êsse prelado. Testemunha-lhe as maiores atenções. Entre os grandes pesonagens convocados a París para a reunião da côrte, ninguém pode ser melhor qualificado do que êle para ocupar, na ilha da Cité, o palácio que a Canção dos Narboneses diz ser o melhor depois daquele do rei. "Carlos Magno", acaba-se de ver pelo resumo do pcema, "tem todo o sangue mudado" (v. 2241), ao saber que se perturbou a paz dêsse alto prelado, cujo alojamento fôra objeto de todos os seus cuidados. Não se percebe quem, a não ser seu venerável tio, poderia merecer, de sua parte, tantas atenções. Insensato seria crer que os narboneses, depois de tal escândalo, pudessem, úm dia, contar com a benevolência de "Carlos Magno". (6). - Parece que não foi sem prazer que Filipe-Augusto ouviu evocar-se Carlos
Magno a propósito de sua pessoa. E' apelidado Karólides em cinco lugares da Philippide, poema que, para a sua-glória, escreveu o seu historiógrafo Guillaume le Breton (II, 485; III, 427; IV, 439 e.528; X, 99). 
Vão expor-se ainda mais perigosamente à sua cólera, ferindo, em outro ponto sensível, sua consciência de soberano. A narrativa do pugilato com os alemães e a inquietação que experimentam os narboneses, quando um dêsses estrangeiros é morto diante do hotel dêles constituem evidentes alusões a um caso que se deu, realmente, em París, no ano de 1200 , e cujo trágico desenlace causou grande impressão, especialmente aos estrangeiros que residiam em París. Um inglês, Rogério de Howeden, deixou-nos do acontecimento minuciosa relação (7), cujo teor é mais ou menos o seguinte:

Nesse mesmo ano de 1200 , houve um grande conflito entre os estudantes e os burgueses de París. Um alemão de família nobre, que fôra proposto para o bispado de Liège, estudava, nessa ocasião, em París. Seu criado teve uma disputa em uma taberna em que entrara para comprar vinho. Bateram-no e quebraram-lhe o cântaro. Os estudantes alemães, disso sabendo, foram em grande número à taberna e surraram o patrão, a quem deixaram meio morto. Disso resultou grande agitação em París. Um grupo de burgueses, à frente dos quais estava o preboste da cidade (8), chamado Tomaz, entrou impetuosamente na casa em que moravam os clérigos alemães. Travcu-se uma luta, no decorrer da qual o nobre clérigo proposto ao bispado de Liège foi morto, juntamente com vários companheiros seus. Os mestres da Universidade de París foram, imediatamente, queixar-se ao rei contra o preboste e seus cúmplices. $O$ rei, cedendo a suas instâncias, ordenou a prisão do preboste e vários dos que o auxiliaram no crime. Como alguns dêstes últimos, abandonando domicílio e bens, tivessem fugido, o rei ordenou que se demolissem suas casas e se arrancassem suas vinhas e árvores frutíferas. Esse exemplo de rigor, deu-o receando que os mestres e estudantes se afastassem de sua cidade de París: timens quod magistri scholorum et scholares a civitate sua recederent.

A fim de desfazer a deplorável impressão que poderia deixar-lhes êsse caso, concedeu-lhes privilégios, alguns dos quais tinham, justamente, o efeito de garantí-los contra os abusos de poder do preboste da cidade. O foral que autorizava tais privilégios foi escrito no decorrer do ano de 1200 , quando o rei se encontrava em Béthisy (9). Manifesta a resolução real de prover, para o futuro, à segurança dos estudantes que faziam seus cursos em $\mathrm{Pa}$ rís, ordinare... de securitate... scholarium in posterum Parisius, e qualifica de monstruoso crime, enorme flagitium, o recente assas:ínio de cinco estudantes alemães.

A êsse extremo rigor, com o qual Filipe-Augusto quer punir tôda falta cometida quanto aos deveres de hospitalidade para com

(7). - Chronica magistri Rogeri de Hovedene, Edição de W. STUBBS, 1871, t. IV, ps. 120-121. Rogkrio de Howeden, desde 1174 , era um dos clérigos a serviço do rei Henrique II da Inglaterra. Sua crônica termina no ano de 1201, pouco depois do gual morreu.

(8). - O preboste da cidade era o chefe de polícia. (Nota do tradutor).

(9). - DENIFLE et CHÂTELAIN - Chartularium Universitatis parisiensis, $t$. 1889 , p. 59 , n. 01 . 
os estudantes estrangeiros, ficarão, pois, sujeitos os jovens narboneses, e nas piores condições possiveis. Ficarão detidos no próprio hotel em que atacaram os alemães, e ao lado do cadáver de um dêles, de cujo homicídio serão inevitàvelmente acusados. Essa culpa capital, acrescida aos atentados que já haviam cometido contra o duque de Borgonha, perde-os irremediàvelmente.

Sem dúvida alguma, a parte da Canção dos Narboneses que narra a permanência dos filhos de Aymeri de Narbonne em París foi composta para um público que ainda se encontrava sob a comoção das escaramuças universitárias do ano de 1200. E se, como parece evidente, é mesmo Guilherme de Champagne que é designado na pessoa dêsse legado pontifical instalado na mais bela vivenda depois daquela do rei, o trecho poderia datar de cêrca de dois anos, pois êsse prelado morreu em 1202. Em todo caso, as alusões às circunstâncias políticas são nele tão evidentes que o poeta teve que ter o cuidado de não se expor a si mesmo, na realidade, a perigos da mesma espécie que aquêles dos quais queria que seus heróis fôssem ameaçados. Pergunta-se, um momento, se êle não vai incorrer na crítica de haver faltado ao respeito para com as instituições reais, ao associar a cenas ridículas uma das mais elevadas dignidades da côrte, a de senescal. Dêsse lado, porém, qualquer perigo estava afastado desde 1191, data em que Filipe-Augusto suprimira o cargo de senescal, que lhe parecia ser de natureza a inspirar ambições demasiado elevadas aos que o exerciam. Na côrte da França, no ano de 1200, não mais havia, portanto, senescal que pudesse ofender-se por ser representado pelo personagem presunçoso e galhofeiro, que, na canção, tem o nome de Arnaldo.

A obra de que estamos tratando constitui o exato eqüivalente do que hoje denominamos revista de atualidade.

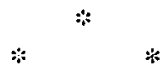

Atuais são as circunstâncias políticas e os sinais de costumes, como atuais os aspectos da cidade. E' a París do ano de 1200 que nesミa canção encontramos, não mais a pequena cidade insular que transparece através dos textos da alta Idade Média, mas já o esbôço dessa grande aglomeração em três partes que, nos planos e documentos oficiais dos séculos XVI e XVII, será qualificada de "Cidade, Centro e Universidade de París", sendo o nome de Cidade ligado aos bairros comerciais da margem direita (do Sena), o de Centro, à ilha central, e o de Universidade, à parte habitada da margem esquerda. No princípio do século XIII, como nunca havia mais que uma ponte sôbre cada um dos braços do Sena, a Grande, sôbre o braço setentrional, e a Pequena, sôbre o meridional, as três partes da cidade denominam-se, ao norte, Além-Ponte-Grande; na parte central, Cité; e, ao sul, Além-Ponte-Pequena. E' pela. 
parte de Além-Ponte-Grande que, como todos os viajantes que percorrem o grande caminho de Orléans, os narboneses chegam a París. E é junto a êsse grande caminho, atualmente denominado rua Saint-Jacques, que se situa a rica vivenda da qual Arnaldo expulsa o duque de Borgonha para alojar o abade de Cluny. Não é em direção aos bairros da margem esquerda que, habitualmente, nos levam as recordações da residência parisiense do duque de Borgonha. O célebre Hotel de Borgonha, que, na história do teatro francês, devia desempenhar conhecido papel, situava-se na outra extremidade da cidade medieval, à margem direita, além da Feira. Essa vivenda, porém, de que ainda hoje subsiste, à rua Etienne Marcel, um fragmento do século XV conhecido pelo nome de Tour Jean Sans Peur, pertencera, mais antigamente, aos condes do Artois. Não passara à posse dos duques de Borgonha a não. ser em consequiência do casamento de Filipe, o Audaz (Filipe VI, de Valois) com Margarida de Artois, em 1369. Antes dessa data, o nome de Borgonha ligava-se a um palácio fortificado situado na ladeira da montanha de Santa Genoveva, num terreno atualmente compreendido, em parte, pela cêrca do Colégio de Santa Bárbara, e, em parte, pela do Liceu Louis-le-Grand, e, portanto, muito próximo à rua Saint-Jacques. Uma das vias adjacentes, entre a rua das Sete-Vias (atualmente rua Valette) e a rua da Carreteira, tomara, desde o século XIII, o nome de rua do Duque de Borgonha, que figura numa lista rimada das ruas de París (10), que data dos anos de 1290-1300. Vendido, em 1412, pela família ducal, a fim de servir de moradia para os mestres e alunos naturais da diocesede Reims, transformou-se o palácio no Colégio de Reims, que subsistiu até à Revolução (seus edifícios foram incorporados aos do Cclégio de Santa Bárbara), ao passo que a rua do Duque de Borgonha tomava o nome de Reims, que conservou até à sua supressão, em 1830. No inventário dos títulos do Colégio de Reims, o ato de venda do ano de 1412 é assinalado como tendo por objeto "um grande palácio cercado de altos muros de pedra de cantaria, pátio, jardim, habitação, dependências, chamado antigamente Hotel de Borgonha" (11).

O local, vizinho à entrada meridional de París, o aspecto de casa fortificada, o nome de Borgonha, êsses três sinais distintivos da vivenda encontram-se, dois séculos antes, na Canção dos Narboneses, que nos informa, também (v. 2050-51), que, na ausência do duque, era a casa guardada, em nome do rei, por um rico burguês que tinha o título de hospedeiro. $O$ aparelhamento defensivo, indicado, no verso 1990 , pela referência às ameias e contrafortes (querniax et pilers) justifica-se pelo fato de o lugar estar ainda.

(10). - Le Dit des Rues de Paris, em Abade LEBEUF, Histoire de la ville et de tout le diocèse de Paris, edição de A. Augier, t. I, 1883, p. 354.

(11). - Segundo BERTY (A.), LEGRAND (H.) e TISSERAND (L.-M.), Topogragraphie historique du vieux Paris, t. VI Réßjon centrale de l'Université, 1897. p. 562. 
fora do muro da cidade, como, na mesma época, à margem direita, os mosteiros do Templo e de Saint-Martin-des-Champs, cada um dos quäis possuia suas fortificações particulares. Apenas em 12.12 é que, pela construção de novo muro à margem esquerda do Sena (12), a montanha de Santa Genoveva foi encerrada, inclusive a abadia, no perímetro fortificado da cidade de París.

$\mathrm{Na}$ ilha da Cité, onde os jovens narboneses realizam sua segunda proeza parisiense, êsse palácio que a canção diz ser o mais belo depois daquele do rei, e situar-se à beira do Sena, no bairro da Fequena Ponte, é, certamente, o que, na segunda metade do século doze, construiu o bispo Maurício de Sully, cujo nome consta no obituário da igreja de París, seguido da seguinte referência: domos episcopales novas aedificavit (13), construiu o novo edifício episccpal. O poema declara que se trata de uma construção que assenta sôbre pilares (v. 2116). Os documentos históricos não são suficientemente pormenorizados para permitirem verificar-se essa indicação; sabemos, porém, que, no fim da Idade Média, o Hospital, contíguo ao palácio episcopal, apresentava o aspecto de construção de parede saliente, apoiada sôbre pilares, acima do Sena (14). Cêrca do ano de 1175 , o palácio recentemente construído por Maurício de Sully (domus nova episcopi) podia exercer a função de residência real. O tio do rei, Guilherme de Champagne, que era, na época, arcebispo de Sens, aí presidiu, entre 1168 e 1176 , importante reunião capitular (15), e foi nesse mesmo palácio que Luiz VII, sentindo aproximar-se o seu fim, convocou, em 1179, a reunião plenária dos arcebispos, bispos, abades e nobres do reino a fim de declarar sua decisão de elevar seu filho Filipe ao poder real (16). Segundo mostram várias gravuras e desenhos do século XVII, o edifício conservava ainda o seu caráter medieval quando o cardeal de Noailles mandou demolí-lo em 1697, a fim de substituí-lo por moderno palácio, o qual, por sua vez, foi demolido, após o saque de 1831, tendo sido em seu terreno localizada a atual Praça do Arcebispado.

Se os lugares designados na narrativa das façanhas dos narboneses são exatamente descritos sôbre a margem esquerda do Sena e na ilha da Cité, há todos os motivos para crer-se que também o sejam sôbre a margem direita, e que, portanto, havia, de fato, no ano de 1200 , em uma encruzilhada do bairro de Além-GrandePonte, uma reputada hospedaria, a que se ligava o nome do lendário Rolando. Sôbre êste ponto, entretanto, não permitem os docunientos históricos estabelecer-se senão uma probabilidade. Um título de renda de 1563 atesta que, à rua Saint-Germain-l'Auxerrois, uma das três casas mais próximas à "esquina da Porta de $\mathrm{Pa}$ -

\footnotetext{
(12). - Chronique de Guillaume le Breton, edição DELABORD (H.F.), 1882, ps. (13). - MORTET (V.), Étude sur la cathédrale de Faris, 1898, p. 73.

(14): - COYECQUE (E.), L'Hôtel-Dieu de Paris au moyen fase, 1891, t. I, p. 162.

(15). - MORTET (V.), Etude sur la cathédrale de Paris, 1888, p. 74.
(16). - RIGORD, Gesta Philippi Augusti, edição DELABORD (H.F.), 1882, ps. 9-10.
} 
rís", isto é, à encruzilhada formada pela intersecção da rua SaintDenis, tinha como insígnia la Table Roulland (17). Essa mesma casa é chamada de la Table Rolant em uma transação de 1469 em que intervém o bispo de París (18). Mais ou menos um século antes, pelos meados do século XIV, um título de renda relativo aos capelães de Notre-Dame denomina a casa "de la Table Rolant, diante do Matadouro de París" (19).

Para se dar uma confirmação histórica à Canção dos Narboneses, restaria demonstrar que a chamada casa da Table Roland em meados do século XIV era dêsse modo denominada desde um século e meio, pelo menos. Nada de inverossímil haveria nisto. Uma denominação que se sabe ter sido associada à mesma casa desde o meio do século XIV e até ao do XVI pode, fàcilmente, remontar ao século XIII, ou, mesmo, ao XII.

O testemunho da Canção dos Narboneses, sôbre a topografia e ós monumentos de París perto do ano de 1200, não deixa, pois, de ter valor. Para que uma farsa ou uma revista de atualidades sejam divertidas, é preciso nelas reconhecer, ao lado das caricaturas e exageros, muitas realidades bem fielmente representadas. Encontram-se, neste poema, os aspectos familiares da vida parisiense e pormenores materiais a que, na época, se dava importância, como, por exemplo, a possibilidade de comprar-se peixe fresco de mar. No verso 2402 há uma alusão a isso, a propósito do banquete que os narboneses preparam no hotel do qual ac'abam de expulsar os alemães.

No estado em que, na Idade Média, se encontravam os meios de comunicação, a chegada de peixe fresco de água salgada a $\mathrm{Pa}$ rís constituia fato notável, que supunha não sòmente o emprêgo de um sistema de transportes acelerados (20), que percorriam um itinerário balizado de estações de muda de cavalos, como também a eliminação de todo obstáculo que resultasse das divisões de soberanias.

$\mathrm{Na}$ realidade, é sòmente no reinado de São Luiz, após a reunião da Normandia ao domínio real, que aparecem, nos atos reais, os primeiros vestígios dessa espécie de comércio. Sôbre êste ponto, porém, como sôbre alguns outros, o testemunho da Canção dos Narboneses antecipa-se ao dos documentos históricos. Propõe a

(17). - Ar:hives Nationaux, S 1080.

(18). - Ib:dem.

(19). - Ibid. S 848 B - O Matadouro de París, mencionado desde o século XII (veja-se LUCHAIRE (A.), Etudes sur les actes de Louis VII, 1885, p. 198, n. 305), figura, ainda, em planos do princípio do século XVIII. (Por exemplo: Arch. Nat. Q I 10994 fo 77 vo). Ocupa, imediatamente ao norte do Châtelet, a praça que se abre na junçāo da rua Santi-Germain-I'Auxarroi com a rua Sain-Denis.

(20). - Provàvelmente a cavalo, e em condições comparáveis às descritas por Chevalier; chefe municipal de Argenteuil na época da Revolução: "Antes de se estabelecer a estrada real n. ${ }^{0}$ 14, de París a Ruão, ao Havre a a Dieppe, construída de 1720 a 1730 , o transporte de mercạdorias não muito volumosas e que exigiam rapidez, como, por exemplo, o peixe fresco, fazia-se a cavalo. Cada tropeiro conduzia dez ou doze cavalos de Pontoise". CHEVALIER (E. O.), Notices'sur la commune et l'hospice d'Argenteuil, 1859, p. 97. 
questão de saber-se se duas das mais antigas possessões marítimas de Filipe-Augusto, Saint-Valery-sur-Somme e o burgo de Ault (21), que estão, ainda no século XVII, ocupadas em enviar para París grandes quantidades de peixe fresco de mar por sommes, isto é, por cargas transportadas a cavalo, não começaram o seu tráfico desde o tempo em que o tratado de Boves, em 1185, abriu ao rei da França um caminho direto para o Ponthieu.

De qualquer modo, é na Canção dos Narboneses que se encontra o mais antigo vestígio do valor que, na Idade Média, os parisienses atribuiam à possibilidade de se abastecerem de peixe fresco de mar. Tal vantagem, nova, provàvelmente, nos tempos de que fala o poema, era, a semelhante distância do mar, excepcional, e ainda o era na época de Carlos VI, quando, na sua famosa balada do Adeus a París, escrevia Eustache Deschamps:

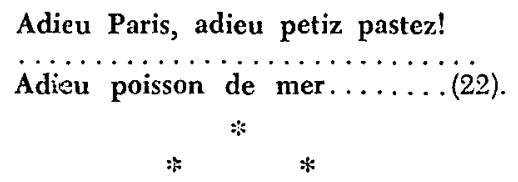

Ainda mais do que pela exata pintura do pormenor familiar, interessa-nos a Canção dos Narboneses pelo reflexo que dá das profundas mudanças que, na França, acompanham a ascenção do poder capetíngio. Põe ela em cena um monarca a quem chama de Carlos Magno, mas exprime um sentimento que teria sido incompreensível aos contemporâneos de Carlos Magno, o sentimento de que París é o lugar a que deve necessàriamente ir e no qual deve residir temporàriamente quem quer que queira fazer bela carreira, a serviço do soberano. O poeta desenvolve êsse tema com tal amplitude, que faz pensar que, na alma dos nobres que o ouviam, a ambição de enviar a París filhos de boa aparência, sôbre os quais possam cair os benévolos olhares do rei, era tão forte quanto, na alma dos seus antecessores, pudera sê-lo a impaciência em vibrar grandes golpes sôbre os sarracenos.

A cena da partida dos filhos para a côrte é tratada como um dos assuntos de muito seguro efeito, do qual pôde o autor explorar tôdas as possibilidades sem correr o risco de fatigar o auditório. Sabia o poeta tocar uma fibra sensível, descrevendo as preocupações, os cuidados e as esperanças que enchiam a alma dos pais ao chegar o momento da partida.

A comoção, no interior do castelo senhorial e na cidade que dêle depende; as afetuosas demonstrações dos burgueses que, incorporados, vão ter com o velho conde, suplicando-lhe que não deixe partir os filhos, e que, vendo que a decisão é irrevogável, en-

(21). - DEVISME (G.), Histoire de la châtellenie d'Ault, cita, à página 11, nota 2 , uma confissão de 1184, que mostra que, desde essa data, o senhor de SaintValery e de Ault reconhece a suserania do rei da França.

(22). - Citado por POETE (M.), Une vie de cité, Paris de sa naissance à nos jours, t. I, 1924, p. 538 . 
viam, igualmente, vários de seus filhos, para tentarem fortuna juntamente com os do seu senhor; o cuidado da condessa em prover as bagagens, aumentado-as, às escondidas, com tôda espécie de boas e belas coisas, a ponto de torná-las tão volumosas que seus filhos dispensam parte delas; o comovente instante da despedida e a formação, pela gente do lugar, de um séquito que caminha, por certo tempo, ao lado dos jovens viajantes; mais longe, o risco de errarem o caminho, através de tantas regiões desconhecidas, o perigo dos salteadores, em plena estrada, a dificuldade de hospedagem em París, e, finalmente, a esperança de que os filhos não deixarão de encontrar algum parente, ou amigo, que os ajude a sair de situações difíceis, tudo isso constitui uma das partes do poema que mais intensidade apresentam. Aos nobres que o ouvem, e que também enviaram a París, junto ao rei, filhos cujas notícias esperam, sugere o poeta o aprazível pensamento de que, se os jovens cometerem ruidosas extravagâncias, o nome de que são portadores não contribuirá pouco para poupar-lhes o desgôsto de ter que responder por elas perante a justiça real. Agrada, na alma paterna, a secreta certeza de que os filhos farão notar-se, em París, por seu aspecto simpático e boa presença, como êsses jovens nobres narboneses, dos quais, vendo-os cavalgar nas ruas da cidade, dizem os transeuntes: "Que elegância! Jamais se viu jovens tanto se parecerem uns com os outros, como aquêles seis que vão a cavalgar. Bem parece, por seus modos, que são filhos de conde..." (v. 2315-2319).

0 instante que proporciona às intimas aspirações do auditório a mais completa e exaltadora satisfação é aquêle em que o rei diz aos filhos de Aymeri de Narbonne da muito especial estima que por êles tem, e lhes confere as altas dignidades que seu pai desejava para êles, armando-os cavaleiros com sua própria mão.

\footnotetext{
"Grant merciz, sire", ce dient li baron.

Lors sïajenoillent san' nule arestoisson

Trestuit li frerre devant les piez Charlon (v. 2865-2867).

"Muito obrigado, senhor", dizem os nobres - Ajoelham-se, então, sem mais tardança - Todos os irmãos aos pés de Carlos).
}

E' a essa cena de adoração da majestade real que, cêrca do ano de 1200 , tende uma narrativa que lisonjeia as mais altas ambições da aristocracia. Grande é a distância entre o estado de espirito refletido pela narrativa e o dos nobres do XI século e princípios do XII, que, pela pena dos seus historiógrafos, davam a entender ao rei que êste não conservaria o seu reino, não fôsse o poder e a bravura dêles.

São poucas, enfim, as obras que, melhor que essa canção de gesta, mostram como essa consolidada autoridade real preparava excepcionais destinos à cidade que gozava do privilégio de ser a sua sede. Constitui quadro muito expressivo e rico de sentido o da agitação que o apêlo do rei provoca, até mesmo nos mais lon- 
gínquos feudos; a pintura da animação criada, no grandt chemin ferré, (grande estrada calçada), pelos séquitos dos grandes senhores e altos dignatários eclesiásticos, chamados para darem seus. conselhos. Essa assembléia, cuja convocação tanto e tão profundamente agita o mundo feudal, o poeta dá-lhe nome. E' a côrte, curia regis, dizem os atos reais do século XII o órgão essencial, e, poder-se-ia dizer, polivalente do govêrno real, o conselho dos grandes, leigos e eclesiásticos, de que se cerca o rei, a fim de tomar as importantes decisões, e, mais comumente, para exercer sua função de grande justiceiro.

$\mathrm{Na}$ época a que nos transporta a Canção dos Narboneses, a côrte, em conseqüência do aumento do poder real, em extensão como em eficiência, tornou-se, como emanação do poder judiciário do rei, um corpo demasiado importante para poder, como no tempo dos primeiros Capetíngios, acompanhar fàcilmente o soberano em tôdas as suas mudanças de lugar. Precisa de permanente ponto de ligação, que é, naturalmente, a residência habitual do rei, isto é, o palácio da Cité, em París. Como já se notou, o seguinte verso da Canção dos Narboneses:

Al parlement à Paris la cité (v. 1822)

No Parlamento, na ilha de París

contém a palavra que, nos documentos da segunda metade do século treze, designa a Côrte de Justiça, como sede fixa, dotada de escritórios e arquivo.

O que, porém, a Canção dos Narboneses encerra de mais original e mais precioso para a história do desenvolvimento de París é, certamente, a descrição da afluência suscitada pelas convocações da côrte. Deve-se, entre outras curiosas indicações, pôr em relêvo a menção (v. 2261-2262) de um prado próximo à beira do Sena, onde o legado pontifical e os prelados que o acompanham vão fazer sua tenda, após haverem sido expulsos do palácio da ilha da Cité. Outros textos da segunda metade do século XII ou do comêço do século' XIII, históricos ou lendários, assinalam, em $\mathrm{Pa}$ rís, ajuntamento de multidões e acampamentos sôbre 0 prado. Um local era apropriado para isso: o terreno baixo, e não construído, por ser sujeito a inundações, que se estende de Saint-Germain-des-Prés até à margem escarpada do Sena, a pequena distância abaixo da extremidade ocidental da ilha da Cité. Êsse espaço figura, ainda em meados do século XVI, sem construções, no plano de Truschet e Hoyau, que the dá o nome de "Prado dos: Clérigos". Mais antigamente, pelo ano de 1415, bem conhecida miniatura, que fazia parte das Riquíssimas Horas do duque de Berry, representa, no mesmo lugar, uma cena de corte do feno, diante do Palácio da Cité, cujas tôrres e pináculos se delineiam no horizonte próximo. E' nesse mesmo prado que, em abril de 1163, o papa Alexandre III, após haver consagrado a igreja de: 
Saint-Germain-des-Prés, recentemente reconstruída, pronunciou uma alocução diante da multidão aglomerada (23).

Là encore,

Sous Saint Germain, enmi las prés floris, à Paris,

Lá, ainda, em Paris, em Saint Germain; entre os prados floridos,

Lá, ainda, em París, em Saint Germain, entre os prados floridos, um poema épico do século XII, o Moniage Guillaume, diz que acampa o exército que o rei Luiz se prepara a conduzir contra os pagãos (24), e é para êsse mesmo lugar que se dirigem, necessàriamente, os olhos de "Carlos Magno", quando, em Renaud de Montauban, outra canção de gesta do tempo de Filipe-Augusto, vê, pelas janelas do seu palácio, reunirem-se os seus barões nos prados, à beira do Sena (25). O autor de um estudo sôbre París nos poemas épicos da Idade Média admite que, no século XII, tinham os nobres o hábito (26) de alojar-se sob uma tenda, nesse prado da beira do Sena, quando eram convocados pelo rei a París. A Canção dos Narboneses mostra-nos, em todo caso, que, pelo ano de 1200 , longe estava, ainda, a cidade de poder conter a afluência dos homens do clero e da nobreza chamados ou atraídos pelas reuniōes da côrte, e que sòmente altos personagens que gozavam da muito especial proteção do rei, como o duque de Borgonha, ou mesmo de sua veneração, como o legado, seu tio, podiam ter a certeza de conseguir alojamento condizente com as exigências de sua posição social. Constituiria êrro considerar como pura fantasia, inventada para o efeito cômico, a idéia de fazer com que pernoitassem sob uma tenda êsse legado e seus dois arcebispos. Seu assombro é, sem dúvida, divertido; não se manifesta, porém, de modo tão absurdo, nem tão ridículo: ir acampar no prado significa, simplesmente, reunir-se ao grupo de barões que, desde a sua chegada, se instalaram dêsse modo.

Os episódios parisienses da Canção dos Narboneses fazem com que bem se compreenda o quanto podia ser vivo, entre os grandes, o desêjo de adquirir e pôr em ordem, na cidade uma habitação de reserva, em proporção com a sua comitiva e com a duração de suas estadas junto do rei. Não tardará em vir um tempo em que, ao terem que morar temporàriamente em París, a fim de cumprirem os seus deveres de côrte, ou defenderem os seus interêsses, os abades de Cluny não terão mais que recear desventura como a que a Canção dos Narboneses atribuiu a um dêles, do qual se lembra o colóquio com o jovem Arnaldo, no momento em que, não tendo conseguido encontrar hospedagem na cidade, faz meia volta com seus monges, para procurar pousada no campo. Bem perto dessa Grande Rua pela qual entravam em París, ao virem do sev

(23). - LASTEYRIE (R. de), Cartulaire énérale de Paris, t. I, 1887, p. 376.

(24). - Le Moniage Guillaume, versos 3728-3734 (Ed. W. CLOETTA).

(25). - Renaus de Montauban, Edição MICHELANT, (H.), 1862, v. 950-951.

(26). - OLSHKI, Paris nasch den altfanzösischen nationalen Epen. Topographia. Stadgeschichte und lokale Sagen, 1913, p. 83. 
longínquo mosteiro, adquiriram, no século XIV (27) as ruínas romanas denominadas Palácio das Termas (domum quae dicitur Palatium de Terminis seu Thermis), a fim de aí construírem, prevendo suas estadas temporárias junto à côrte, o palácio que tem, atualmente, o nome dêles, e que nos aparece revestido da elegante forma que, perto do ano de 1500, the deu o abade Jacques d'Amboise.

Muitos dos prelados ou senhores convidados a participar dos conselhos do rei agiram do mesmo modo, de maneira que foram numerosas, em París, no fim do período capetíngio, as construções de vivendas principescas. O primeiro grupo, do qual, desde o sérulo XIII, fazem parte os palácios de Flandres (28) e de Nesles (29), aparece não longe do Louvre, o novo castelo real, no bairro de SaintEustache, onde os construtores encontram, na época, terrenos livres, que não existiam na antiga Cité, há muito tempo coberta de construções. Sabe-se que outros conjuntos̀ deviam formar-se na parte oriental da cidade, a partir do reinado de Carlos V, no bairro do $\mathrm{Ma}$ rais, e, mais tarde, ainda, na parte ocidental, nos bairros de Saint Honoré e da Ville de l'Evêque, depois de Catarina de Médicis haver decidido a construção do Palácio das Tulherias. Finalmente, na época dos Bourbons, a construção da Ponte Nova, e, posteriormente, a da Ponte Real, abriram às emprêsas aristocráticas o acesso à parte da planície que, do outro lado do Sena, se situa em frente ao Louvre e às Tulherias. Com o aumento do número de palácios providos de porta grande para a entrada de carruagens, desapareceram, então, êsses prados de Saint Germain em que haviam acampado os nobres do século XII.

Essas sucessivas mudanças de lugar da parte mais importante das construções asseguraram ao crescimento da aglomeração parisiense certo $\in$ quilibrio, que se manifesta pela forma quase circular que apresentava a cidade, no fim do século XII, no interior de sua faixa de alamedas. Foram, com efeito, os palácios senhoriais que, durante os seis séculos do período monárquico, do século XIII ao

\footnotetext{
(27). - Segundo MARRIER (M.) (Martinus Marrier) " DUCHESNE (A.) (Andreas Quercetanus), Bibliothece cluniacensis, 1614, col. 1671, a compra foi feita pelo abade Pierre de Châlus $(1322-1344)$. Realizou-se em 1334 (LE ROUX DE LINCY, Recherches sur ies propriétaires et les habitants du Palais des Thermes et de l'Hôtel de Cluny... dans l'intervalle des années 1218 à $1600 \mathrm{em:} \mathrm{Mémoires} \mathrm{de} \mathrm{la} \mathrm{Seciéte} \mathrm{royale} \mathrm{des} \mathrm{Antiquaires} \mathrm{de} \mathrm{França,} \mathrm{t.}$ XVIII, 1846, ps. 30-31).

Desde a segunda metade do século XIII, os abades de Cluny possuíram, em París, sua primeira casa, situada mais alto, no declive da montanha de Sainte Geneviève, à rua de la Harpe, no espaço atualmente limitado pelo Boulevard St. Michel, pela praça da Sorbonne e pela rua Victor Cousin, que sucedeu à antiga rua de Cluny. Era, ao mesmo tempo, uma habitaçăo para o abade e um colégio no qual moravam monges que estudavam em Paris (ANGER (Dom P.), Le Collège de Cluny fondé à Paris dans le voisinage de la Sorbonne... 1916, ps. 14-15).

A aquisição do Palácio das Termas, no século XIV, corresponde ao desêjo que tinham os abades de, durante suas estadas em París, instalar-se em outro palácio que não o colégio.

(28). - HUISMAN (G.), Un compte des rifparations effectuées à l'hôtel du Comte de Flandre à Paris (1374-1376), p. 4.

(29). - LEBEUF (Abbé), Histoire do la ville et de tout le diocèse de Paris, edição de A. Augier, t. I, 1883 , p. 68 .
} 
XVIII inclusive, ocuparam, em París, a maior superfície, e mais contribuíram para que essa cidade não se assemelhasse a nenhuma outra. A tendência que tinham êsses palácios de agrupar-se e formar, em certos bairros, uma espécie de sociedade, a competição, que fazia com que se procurassem, para cada um dêles, imponentes proporções e nobreza do aspecto, tudo isso exprimia a atração exercida pela pessoa do rei sôbre tudo o que tinha valor na França. Nas proximidades de cada uma das residências sucessivamente preferidas pelo soberano, tais construções aristocráticas constituíram uma série de figurações arquiteturais da côrte. A importância do papsıl desempenhado pelos palácios senhoriais na vida da população parisiense é atestada felo costume, que persistiu até ao fim do Antigo Regime, de se dar seus nomes, isto é, os de seus donos, às ruas vizinhas. Profissionais e comerciantes, que encontravam nessas casas tôda espécie de empregos ou oportunidades para ganhar dinheiro, sabiam de cor a localização das mesmas, como, na época da Restauração, êsse cocheiro de carruagem de aluguel a quem um personagem de Balzac, Engênio de Rastignac, diz apenas, para que aquêle o conduza: "Ao palácio de Beauséante".

Esse caráter particular que a vida aristocrática deu ao crescimento de París, a Canção dos Narboneses, justamente, faz com que os compreenda a sua razão de ser, mostrando, ao mesmo $t \in \mathrm{m}$ po, o seu aspecto econômico. A narrativa da estada dos filhos de Aymeri de Narbonne em París introduz-nos em uma cidade em que a côrte já constitui, tanto para os hospedtiros como para os artífices, fonte de lucros essenciais. Vemos os grandes fazerem ostentação de magnificência, nas festas dadas quando se reunem em tôrno do rei. Distribu€m pròdigàm $n$ nte, como convém à sua posição social,

Chevax et robes et denicrs moneez (v. 3294)

(Cavalos, roupas (' moedas cumhadirs).

Em outra parte da Canção está dito que, após um festim realizado no salão do Palácio,

Maint bon henap et maint copc ovree

Qui al meng: or of esté aportec

Ont li baron departic et donce. (v. 3304-3306).

(Os nobres repartiram e deram muitas boas taças grandes e muitos copos lavrados que foram trazidos ao banquete).

E' o que a condessa Hermengarda tinha em mente por ocasião da partida de seus filhos. Lá longe, em París, pensava ela, "Encontrarão a rica baronia" (v. 810 ). Por isso, vai procurar para êles, na grande tôrre do castelo condal,

O mout avoit avoir et menetie ( $v .820$ ).

(onde havia muito dinheiro e riquezas), 
ouro fino, aquêles ricos tecidos de sêda leve que se denominavam cendaux, e as grandes taças de beber, feitas de material precioso, os henas mout chiers (v. 826) que os senhores se orgulhavam de pôr diante de si, por ocasião dos festins da côrte.

Compresnde-se quanto podia ser vantajoso, para os que fabricavam tais objetos, exercer sua arte em París. Imagina-se com que abundância podiam çircular na cidade, durante as reuniōes da côrte, essas moeđas cunhadas de que fala o poeta. Lá estava em $t \in m p o s$ em que muitos senhores ainda cunhavam moedas particulares - uma das razões da importância de que, em París, se revestia a corporação dos cambistas, que exerciam o seu mister bem $\mathrm{p}$ :rto do Palácio, sôbre a ponte ainda hoje chamada Ponte do Câmbio. O que, no século XIII, se podia pensar da quantidade de metal precioso que passava por.suas mãos, encontrâmo-lo expresso em um verso da Canção dos Narboneses, em que já aparece €Ssa maneira, ainda atualmente familiar, de se dizer enèrgicamente não: Je ne vodroie por tot l'or de Paris - (Eu) "não quisera por todo o ouro de París" (v. 756).

Os que esperam seus meios de subsistência do dinheiro largamente espalhado pelos grandes senhores não são ap€nas os cambistas, os ourives, os peleircs, os comerciantes de sêda e os que fabricam os belos equipamentós que "Carlos Magno" envia aos jovens nobres por êie armados cavaleiros. Säo, também, os jograis, isto é, os músicos e os poetas. A canção mostra-os participando das festas dadas em París, durante a reunião da côrte. No serão que precedeu ao dia em que os filhos de Aymeri de Narbonne foram armados cavaleiros pelo rai, não houve harpista, jogral, nem homem que soubesse deduire (divertir ou contar) que não estivesse ocupado em distrair os nobres (v. 3127-3129). E o poita lembra a boa sodée (recsita) que coube a seus colegas durante os três dias de alegria que se seguiram:

Plus de C mars valut jornee (v. 3398 ).

(Mais de cem marcos thes vileu o dia)

Desde êsses tempos, portanto, e por efeito do que um descritor da cidade chamará, mais tarde," "a sociedade de prelados e príncipes que residem habituaimente em París" (30), as produções pelas quais París se distingue são as que, por todos os modos, e no mais alto grau, contribuem para o embelezamento da vida. Tal característico devia sobreviver à Idade Média e à própria monarquia.

Por isso, deve a Canção dos Norboneses ser colocada entre. os textos pelos quais se chega ao conhecimento íntimo de París. Esse velho poema pinta situações e sentimentos que originarão alguns dos característicos da cidade moderna, e o seu testemu--

(30). - La description de la ville de Paris par Guillebert de Metz (anos 1407-1434) em LE ROUX DE LINCY e TISSERAND: Paris et ses historiens aux XIVoet $X V e$ siècles, 1867 , p. 232. 
nho assume todo o seu valor quando é confrontado com o das narrativas mais antigas. Nas tradições concernentes às proximidades do ano 1000, París ainda conserva quase tôda a configuração que adquirira no tempo do Baixo-Império romano. Dois séculos mais tarde, a nave de Notre-Dame, em que os jovens narboneses vão orar (v. 3137 )domina um conjunto urbano que já prefigura a grande cidade de Henrique IV.

O tempo, $\mathrm{em}$ certos períodos da História, parece passar em ritmo mais rápido.

\section{ROGER DION}

Professor da Sotbonne e da "Erole Normale Supérieure" (París). Antigo professor da Faculdade de Filosofia, Ciencias e Letras da Universidade de São Paulo. 